\title{
BMJ Open Definitions and measurement of health literacy in health and medicine research: a systematic review
}

\author{
Kristin Hjorthaug Urstad (D) ,1,2 Marit Helen Andersen,, ${ }^{3,4}$ Marie Hamilton Larsen, 5,6 \\ Christine Råheim Borge, ${ }^{3,7}$ Sølvi Helseth, ${ }^{8,9}$ Astrid Klopstad Wahl ${ }^{3,4}$
}

To cite: Urstad KH, Andersen MH, Larsen MH, et al. Definitions and measurement of health literacy in health and medicine research: a systematic review. BMJ Open 2022;12:e056294. doi:10.1136/ bmjopen-2021-056294

- Prepublication history and additional supplemental material for this paper are available online. To view these files, please visit the journal online (http://dx.doi.org/10.1136/ bmjopen-2021-056294)

Received 11 August 2021 Accepted 15 December 2021

Check for updates

(c) Author(s) (or their employer(s)) 2022. Re-use permitted under CC BY-NC. No commercial re-use. See rights and permissions. Published by BMJ.

For numbered affiliations see end of article.

Correspondence to Kristin Hjorthaug Urstad kristin.h.urstad@uis.no

\section{ABSTRACT}

Objectives The way health literacy is understood (conceptualised) should be closely linked to how it is measured (operationalised). This study aimed to gain insights into how health literacy is defined and measured in current health literacy research and to examine the relationship between health literacy definitions and instruments.

Design Systematic review in accordance with the Preferred Reporting Items for Systematic Reviews and Meta-Analyses statement.

Data sources The MEDLINE, PsycINFO, ERIC and CINAHL databases were searched for articles published during two randomly selected months (March and October) in 2019.

Eligibility criteria We included articles with a quantitative design that measured health literacy, were peer-reviewed and original, were published in the English language and included a study population older than 16 years.

Data extraction and synthesis Six researchers screened the articles for eligibility and extracted the data independently. All health literacy definitions and instruments were considered in relation to category 1 (describing basic reading and writing skills, diseasespecific knowledge and practical skills) and category 2 (social health literacy competence and the ability to interpret and critically assess health information). The categories were inspired by Nutbeam's descriptions of the different health literacy levels.

Results 120 articles were included in the review: 60 within public health and 60 within clinical health. The majority of the articles $(n=77)$ used instruments from category 1. In total, 79 of the studies provided a health literacy definition; of these, 71 were in category 2 and 8 were in category 1 . In almost half of the studies $(n=38)$, health literacy was defined in a broad perspective (category 2) but measured with a more narrow focus (category 1).

Conclusion Due to the high degree of inconsistency between health literacy definitions and instruments in current health literacy research, there is a risk of missing important information about health literacy considered be important to the initial understanding of the concept recognised in the studies.

PROSPERO registration number CRD42020179699.

\section{INTRODUCTION}

Health literacy is usually understood as cognitive and social skills that determine the motivation and ability to understand and use

\section{Strengths and limitations of this study}

To our knowledge, this is the first systematic review to investigate connections between health literacy definitions and instruments used in current health literacy research.

- The health literacy definitions and instruments were categorised based on a health literacy model described by Nutbeam.

- The initial plan to assess health literacy definitions and instruments for three categories was changed to two due to difficulties in distinguishing between two of the categories.

- Searches were limited to two randomly selected months.

health information, ${ }^{1}$ and adequate health literacy is seen as a prerequisite for healthy behaviours. Researchers have increasingly worked to identify challenges associated with health literacy and investigate the role they play in an individual's ability to comprehend self-care information and its relationship to health outcomes. ${ }^{2}$ Empirical studies have reported that low health literacy is associated with poor health-related outcomes, such as high hospital admission rates, ${ }^{3}{ }^{4}$ low participation in preventive activities, ${ }^{5-9}$ poor selfmanagement of chronic conditions, ${ }^{10}$ poor disease outcomes and high mortality. ${ }^{11-13}$

The concept of health literacy emerged in the 1970s when health education was viewed as social policy. ${ }^{14}$ A topic-specific query in the PubMed tools reveals a recent exponential growth of articles about health literacy, with 129 references between 1986 and 1990 increasing to more than 8000 in the past 5 years. Today, health literacy is seen as a global goal for enhancing health promotion through improved education and communication strategies to improve health outcomes. ${ }^{15}$

Health literacy is defined in numerous ways. ${ }^{1416-18}$ In a systematic review by Sorensen 
et al, ${ }^{14} 17$ different definitions and 12 conceptual models were reported on health literacy. Another systematic review found that 34 research articles between 2010 and 2015 had an explicit objective to define the concept of health literacy. ${ }^{17}$ Moreover, the literature has reported the use and development of more than 150 health literacy instruments over the last decade. ${ }^{19-21}$ Traditionally, health literacy approaches have focused on individual skill deficits and health education based on the communication of factual information regarding health risks as well as how to use the health system, ${ }^{22}$ with the majority of health literacy research having used instruments measuring reading and numerical skills. ${ }^{23}$ However, in recent years, more multidimensional perspectives and instruments measuring health literacy have been introduced, such as the Health Literacy Questionnaire ${ }^{24}$ and the Health Literacy Survey European Questionnaire 47. ${ }^{25}$

The current and sometimes confusing use of various and inconsistent interpretations of health literacy is a challenge for the development of valid and reliable measurements. ${ }^{16}$ In 2000, Nutbeam proposed a health literacy model that is now widely cited in the health literacy literature and is seen by many health literacy researchers as useful in analysing health literacy abilities required in various health situations. ${ }^{22}$ According to Nutbeam, health literacy contains three different levels, progressing from basic skills in reading and writing (functional health literacy), to the ability to derive meaning from different forms of communication and apply new information to changing situations (interactive health literacy) and to more advanced cognitive skills which, together with social skills, can be applied to critically analyse information and to achieve policy and organisational changes (critical health literacy).

Different understandings of health literacy and different measurement tools may be useful as they complement each other and provide different perspectives. However, the way health literacy is understood (conceptualised) should be closely linked to how it is measured (operationalised) in each study context. ${ }^{23}$ Nguyen et al has described this as a 'conceptual stumbling block' that needs to be resolved for the field to progress. ${ }^{23}$ A first useful step for addressing this might be to systematically explore how it appears in current health literacy research. Hence, by performing a systematic review, our aim was to gain insights into how health literacy is defined and measured in current health literacy research. In particular, we will examine the relationship between health literacy definitions and instruments. This review may increase our understanding of potential conceptual and methodological challenges or gaps that need to be addressed in future research.

\section{METHODS}

This systematic review was conducted in accordance with the Preferred Reporting Items for Systematic Reviews and Meta-Analyses statement ${ }^{26}$ and registered in PROSPERO (https://www.crd.york.ac.uk/prospero/display_record. php?RecordID=179699). The review was designed with a time frame limited to two randomly selected months in 2019 (March and October). Due to a high number of health literacy articles published every year, random selection was chosen in order to reflect current health literacy

Table 1 Overview of study populations in clinical and public health studies

\begin{tabular}{|c|c|c|c|}
\hline \multicolumn{2}{|l|}{ Clinical health studies } & \multicolumn{2}{|l|}{ Public health studies } \\
\hline Populations classified by diseases and related health problems & $\mathbf{n}$ & Type of study population & $\mathbf{n}$ \\
\hline Diseases in the circulatory system & 11 & General population & 19 \\
\hline Mental illness & 6 & Parents/caregivers & 6 \\
\hline Cancer & 6 & Elderly people & 5 \\
\hline Diseases in the urine and genital organs & 4 & Work-related populations & 3 \\
\hline Infectious and parasite diseases & 3 & Young adults & 2 \\
\hline Diseases in the ear & 2 & Veterans & 2 \\
\hline Diseases in the musculoskeletal system and connective tissue & 2 & Health personnel & 2 \\
\hline Diseases in the nervous system & 1 & Men & 1 \\
\hline $\begin{array}{l}\text { Others: general chronic conditions }(n=2) \text {, chronic pain }(n=3) \text {, patients in } \\
\text { primary care }(n=2) \text {, next of kin }(n=2) \text {, patients in specialist care }(n=1)\end{array}$ & 10 & Churchgoers & 1 \\
\hline Total & 60 & Total & 60 \\
\hline
\end{tabular}




\section{Identification of studies}

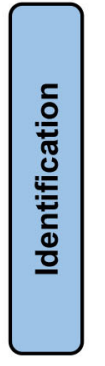

Records identified through searches restricted to March and October 2019

Databases: Medline, PsycINFO, ERIC and CINAHL ( $n=1038)$

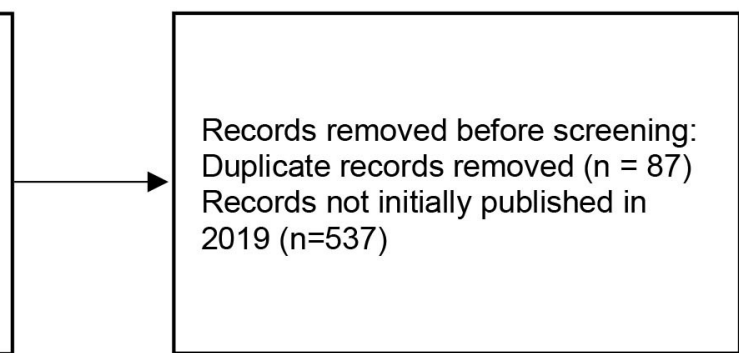

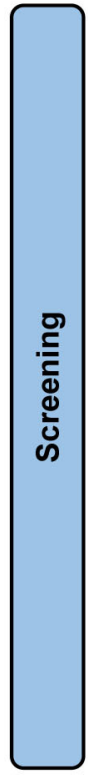

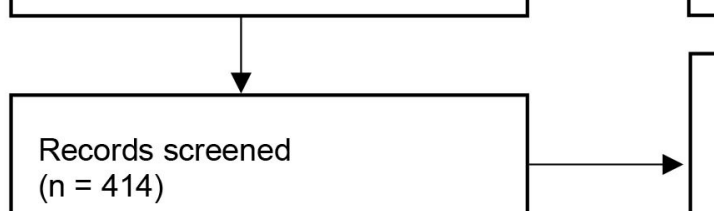

Records excluded ( $n=251)$

Reason1: HL was not mentioned int the title or abstract $(n=35)$

Reason 2: wrong design $(n=115)$

Reason 3: wrong publication type $(n=28)$

Reason 4: wrong population $(n=27)$

Reason 5: wrong outcome $(n=43)$

Reason 6: wrong language $(n=3)$

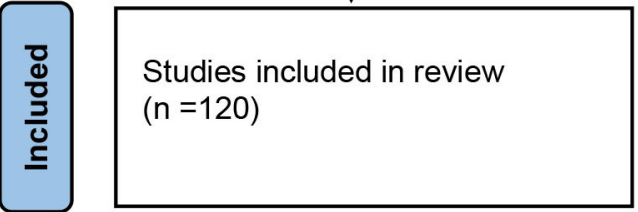

Records excluded ( $n=43$ )

Reason 1: did not measure HL $(n=34)$

Reason 2: duplicate $(n=5)$

Reason 3: wrong language $(\mathrm{n}=2)$

Reason 4: wrong population type $(n=2)$

Figure 1 Flow diagram shows the study selection process. HL, health literacy.

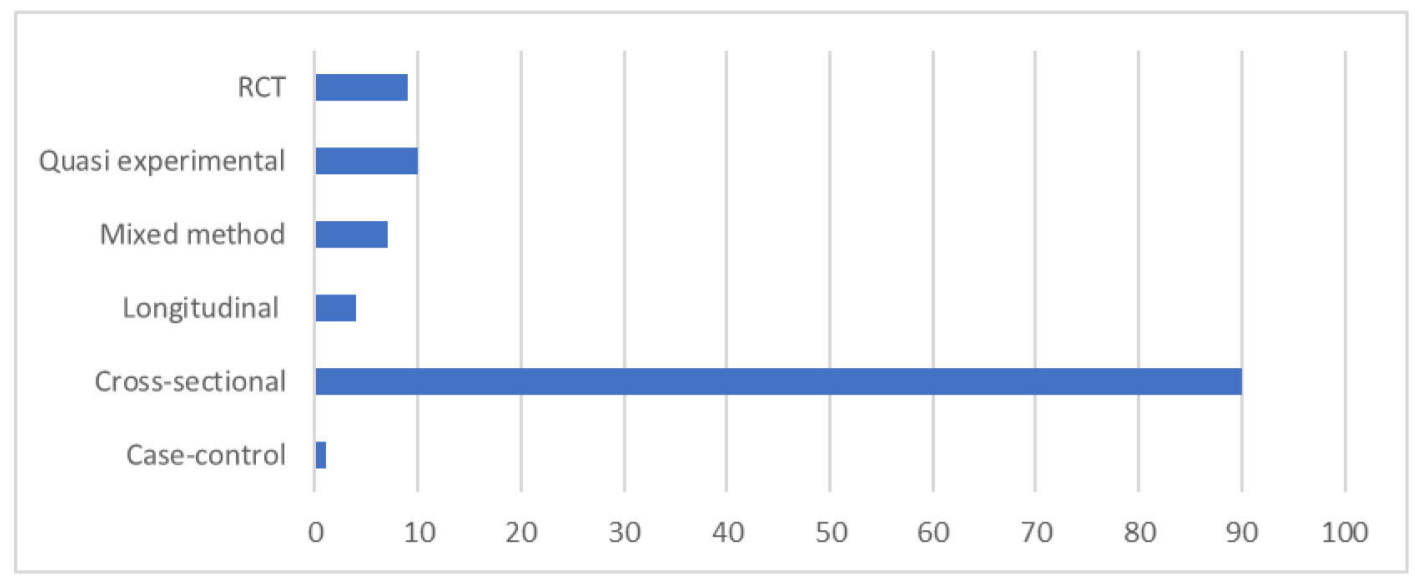

Figure 2 Overview of study designs of included studies. RCT, randomised controlled trial. 


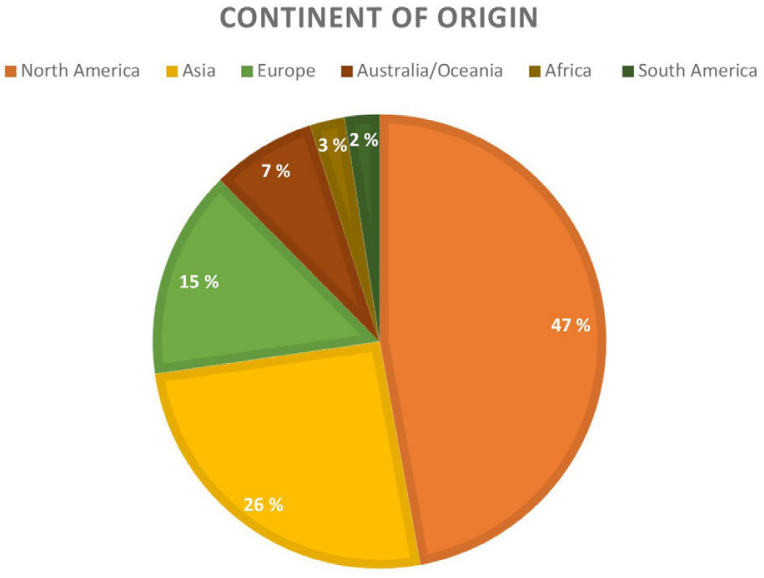

Figure 3 Studies' continent of origin.

research. To ensure that March and October were not unique in terms of the number of articles published, we performed the same search strategy using the same databases for one other randomly selected month in 2019. This search yielded nearly the same number of articles.

\section{Search strategy}

Systematic literature searches were conducted in collaboration with a trained librarian (4 March 2020). The MEDLINE, PsycINFO, ERIC and CINAHL databases were searched for the term 'health literacy'. For all databases except for ERIC (where this was not possible), the search was automatically restricted to two randomly selected months in 2019: March and October. Citations in ERIC were manually assessed for articles published in March 2019 and October 2019.

The search yielded a total number of 1038 citations. Endnote V.X9 was used to manage the generated research articles. After removing duplicates, 951 citations remained. All records not published for the first time in 2019 were removed, leaving 414 articles for screening (see online supplemental appendix 1 for the search history).

\section{Selection criteria}

The inclusion and exclusion criteria were developed a priori. The 414 published articles were distributed among six researchers (KHU, AKW, MHA, CRhB, SH and MHL), who worked in pairs. The articles were included if they fulfilled the following inclusion criteria: (1) 'health literacy' was mentioned in the title or abstract; (2) the article was peer reviewed; (3) the research was original; (4) it used a quantitative design; (5) it was published in the English language; and (6) the study population included individuals older than 16 years of age.

To reduce selection bias, the researchers independently screened the articles for eligibility according to the criteria. They then met in pairs to compare their results, resolve any conflicting opinions and decide whether to include each article. Conflicting opinions in pairs were presented and solved by the whole team.

\section{Data extraction (selection and coding)}

To achieve consistency in the data extracted from the included articles, an Excel V. 2019 spreadsheet was created. The initial question in this spreadsheet was whether health literacy was measured. If the answer was no, the article was excluded. The data extracted from the articles included information about the study design and context, such as country of origin and whether the study was conducted in a public health or clinical health setting. For clinical studies that included participants with health problems, the different types of diseases were categorised according to the International Statistical Classification of Diseases and Related Health Problems. ${ }^{27}$ For the public health studies, we categorised type of study populations

Table 2 Most frequently used references for health literacy definitions in the included studies

\begin{tabular}{ll} 
Reference & Definition \\
\hline $\begin{array}{l}\text { Category 1 } \\
\begin{array}{l}\text { Jorm (1997) } \\
\text { Jorm }\end{array}\end{array}$ & $\begin{array}{l}\text { 'Knowledge about appropriate treatment options; and attitudes that facilitate recognition } \\
\text { and treatment-seeking' } \\
\text { 'Knowledge and beliefs about mental disorders which aid their recognition, management } \\
\text { or prevention' }\end{array}$ \\
$\begin{array}{l}\text { American Medical } \\
\text { Association (1999) }\end{array}$ & $\begin{array}{l}\text { 'The constellation of skills, including the ability to perform basic reading and numerical } \\
\text { tasks required to function in the healthcare environment' }\end{array}$
\end{tabular}

Category 2

\begin{tabular}{ll} 
Nutbeam $^{22} 32-34$ & $\begin{array}{l}\text { 'The cognitive and social skills which determine the motivation and ability of individuals to } \\
\text { gain access to understand and use information in ways which promote and maintain good } \\
\text { health.' }\end{array}$ \\
Sørensen et al ${ }^{14}$ & $\begin{array}{l}\text { 'Health literacy entails people's knowledge, motivation and competences to access, } \\
\text { understand, appraise, and apply health information in order to make judgments and take } \\
\text { decisions in everyday life concerning healthcare, disease prevention and health promotion } \\
\text { to maintain or improve quality of life during the life course.' }\end{array}$ \\
$\begin{array}{l}\text { The Institute of } \\
\text { Medicine }(2004)^{40}\end{array}$ & $\begin{array}{l}\text { 'The individuals' capacity to obtain, process and understand basic health information and } \\
\text { services needed to make appropriate health decisions.' }\end{array}$ \\
\hline
\end{tabular}




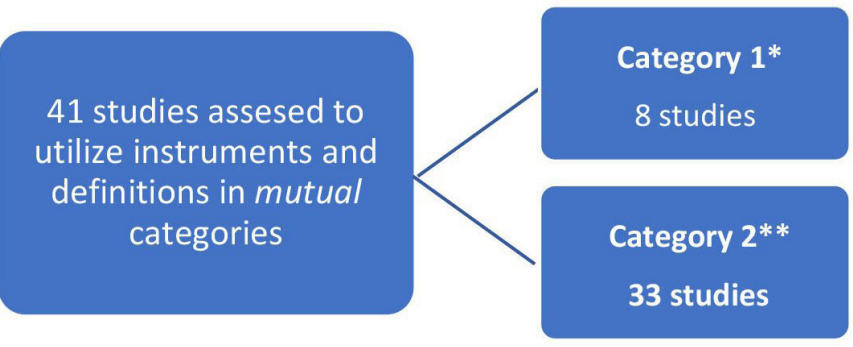

Figure 4 Studies categorised with the same level of HL definitions and $\mathrm{HL}$ instruments. ${ }^{\star}$ Category 1 includes basic reading and writing skills, disease-specific knowledge and practical skill competences. ${ }^{* *}$ Category 2 includes skills to communicate and interact with healthcare providers and the ability to interpret and critically analyse health information. HL, health literacy.

Furthermore, the data included information about whether the instruments were generic or disease specific, whether it was used in combination with other health literacy instruments or if a reference was provided for the instrument.

The published articles were analysed with respect to which health literacy definitions and instruments were used. Before the data extraction, a pilot assessment of three studies was performed to determine the feasibility of the data extraction tool. The initial plan was to assess health literacy definitions and instruments for three categories: (1) functional, (2) interactive and (3) critical health literacy, inspired by Nutbeam's description of different health literacy levels. ${ }^{22}$ As a result of the pilot testing, the number of categories was changed due to difficulties in distinguishing between the two latter levels. All health literacy definitions and health literacy instruments were therefore considered in relation to two categories: category 1 included definitions and instruments describing basic reading and writing skills, disease-specific knowledge and practical skill competencies needed to function in everyday situations; and category 2 included definitions and instruments that also described health literacy as skills to communicate and interact with healthcare providers as well as the ability to interpret and critically analyse health information (online supplemental appendix 2 illustrates the coding for the data extractions).

The researchers first extracted data and considered independently the definitions and instruments related to the two categories. They then met in pairs to compare their results and resolve any conflicting opinions. The remaining conflicting opinions within pairs were presented and solved by the whole team in a group meeting.

\section{Patient and public involvement}

No patient was involved.

\section{RESULTS}

The search yielded 1038 articles in total (see the online supplemental appendix 1 for the search history). After removing duplicates, 951 articles remained. Of the 163 articles that were read in full text, 1 was a duplicate, and 39 were excluded because they did not measure health literacy. Ultimately, 120 articles were included (see figure 1).

\section{Characteristics of included studies}

Sixty articles described studies with a clinical health focus, and 60 were conducted in public health settings. The clinical studies included a great variety of diseases, but the most frequent diseases were those in the circulatory system $(n=11)$ and endocrine diseases $(n=9)$ followed by mental illness $(n=6)$ and cancer diseases $(n=6)$. In the public health studies, the most frequent study group was the general population $(n=19)$, looking into aspects such as vaccination programmes, oral care and mental health. Furthermore, a major part of the public health studies included students $(n=13)$, mainly represented by health professional students. Six studies focused on parents/ caregivers, while five studies focused on the elderly population.(table 1)

The majority of the studies used a cross-sectional design $(\mathrm{n}=90)$. Nine studies used a randomised controlled design, and 10 studies were quasi-experimental. Four of the studies used a longitudinal design, while one was a case-control study. Figure 2 presents an overview of all study designs.

As figure 3 indicates, the majority of studies were conducted in North America $(n=56)$ and Asia $(n=31)$. The fewest studies were performed in Africa $(n=4)$ and South America ( $\mathrm{n}=3)$.

\section{Health literacy definitions and instruments}

Out of the 120 included studies, 88 used generic health literacy instruments, while 32 were context-specific. Eleven studies used a combincation of health literacy instruments. A total of 77 studies used instruments from category 1 (describing basic reading and writing skills, disease-specific knowledge and practical skills), whereas 43 instruments were from category 2 (describing communication and interaction skills and/or the ability to interpret and critically analyse health information). The most frequently used health literacy instruments in category 1 were Newest Vital $\operatorname{Sign}^{28}(\mathrm{n}=19)$ and Test of Functional Health Literacy ${ }^{29}(n=13)$. The most frequently used health literacy instruments in category 2 were The European Health Literacy Survey Questionnaire ${ }^{30}$ and The eHealth Literacy Scale ${ }^{31}(\mathrm{n}=10)$.

Of the 120 articles, 79 provided a health literacy definition. Of these, 46 were public health studies and 33 were clinical health studies. Only eight studies provided a definition addressed to category 1 . Five out of these eight studies focused on mental health challenges.

The most frequently used reference in category 2 was Nutbeam. ${ }^{22} 3233$ The most frequently used reference in category 1 was a definition provided by Jorm and colleagues. ${ }^{35} 36$ Table 2 gives an overview of the text in 


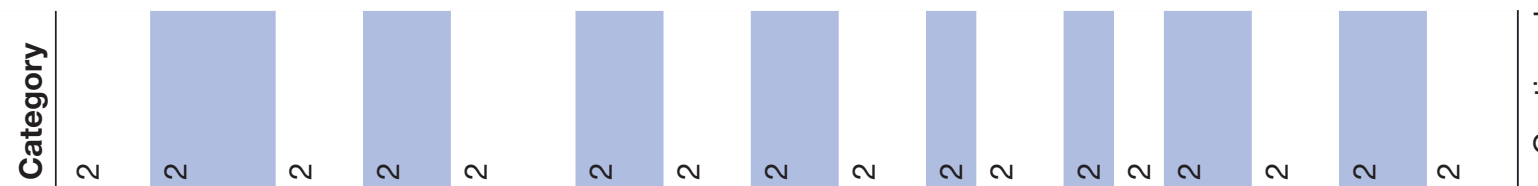

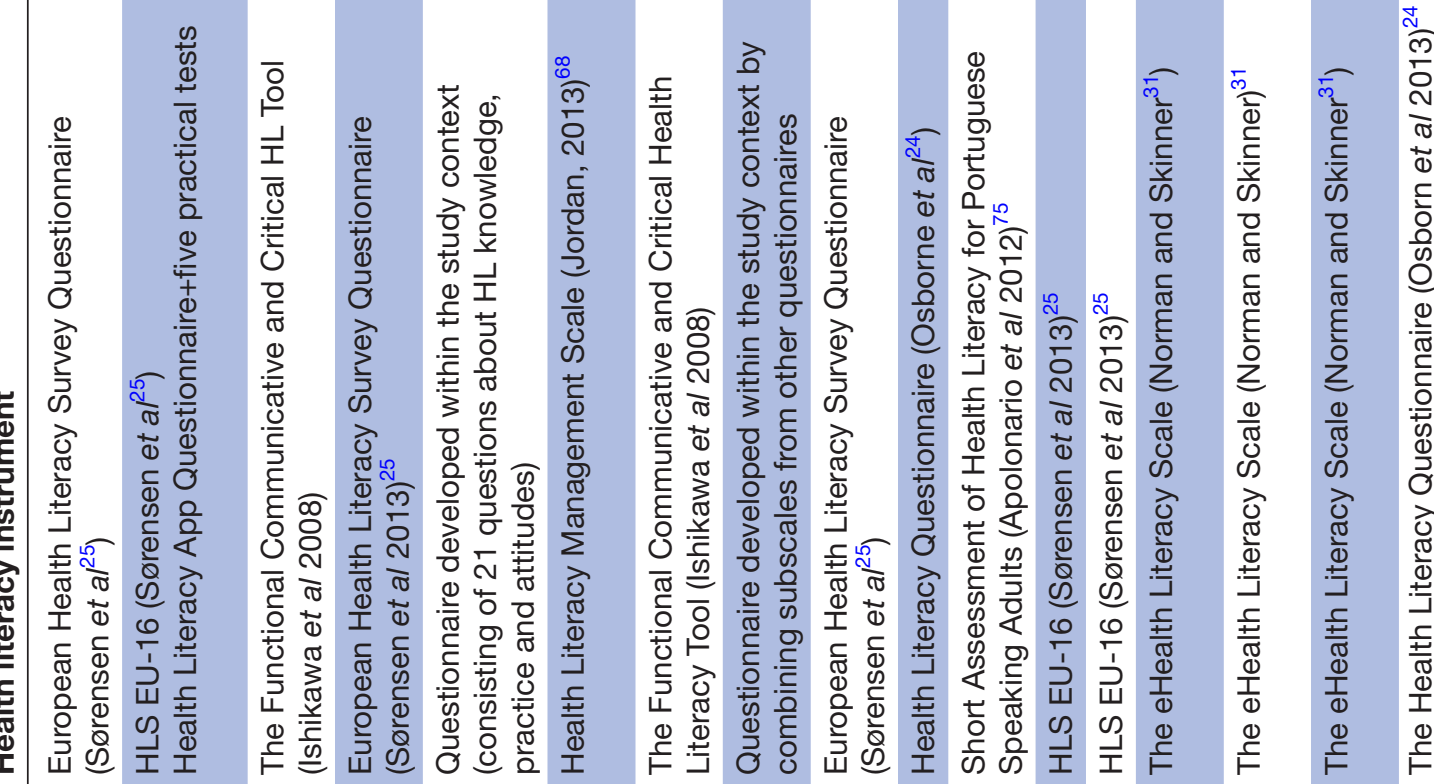
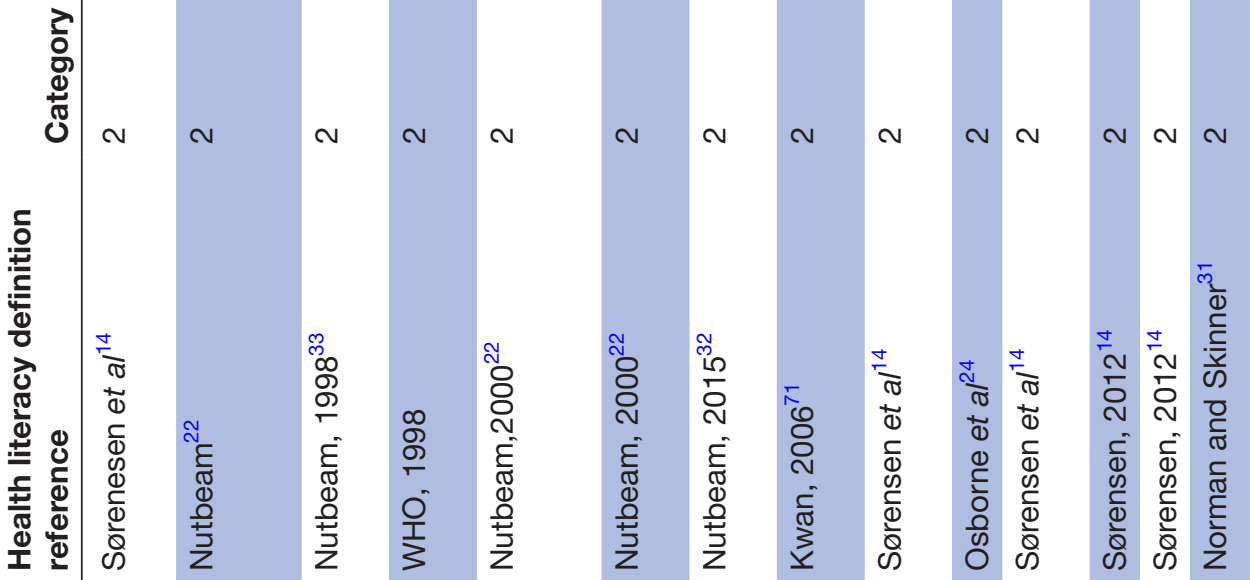

$N \quad N$

음

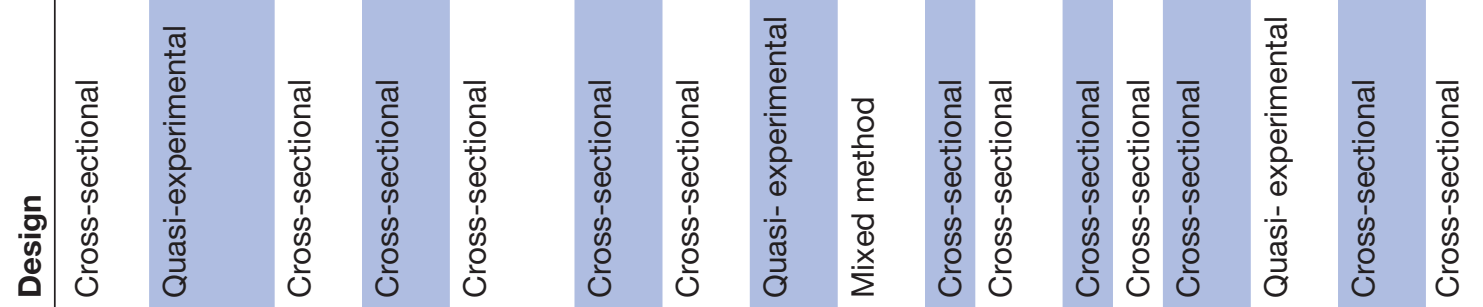

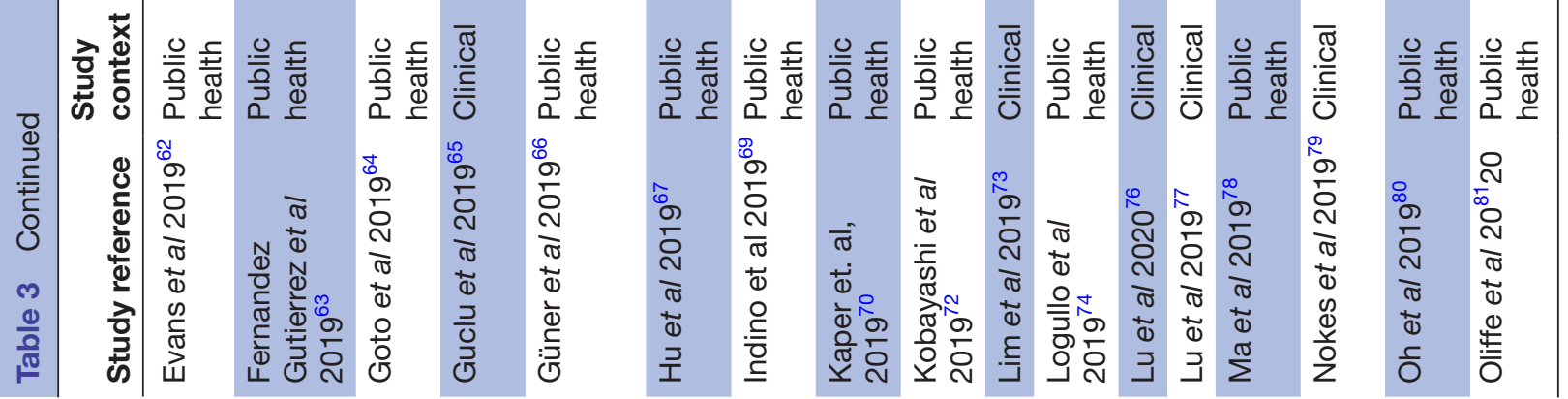




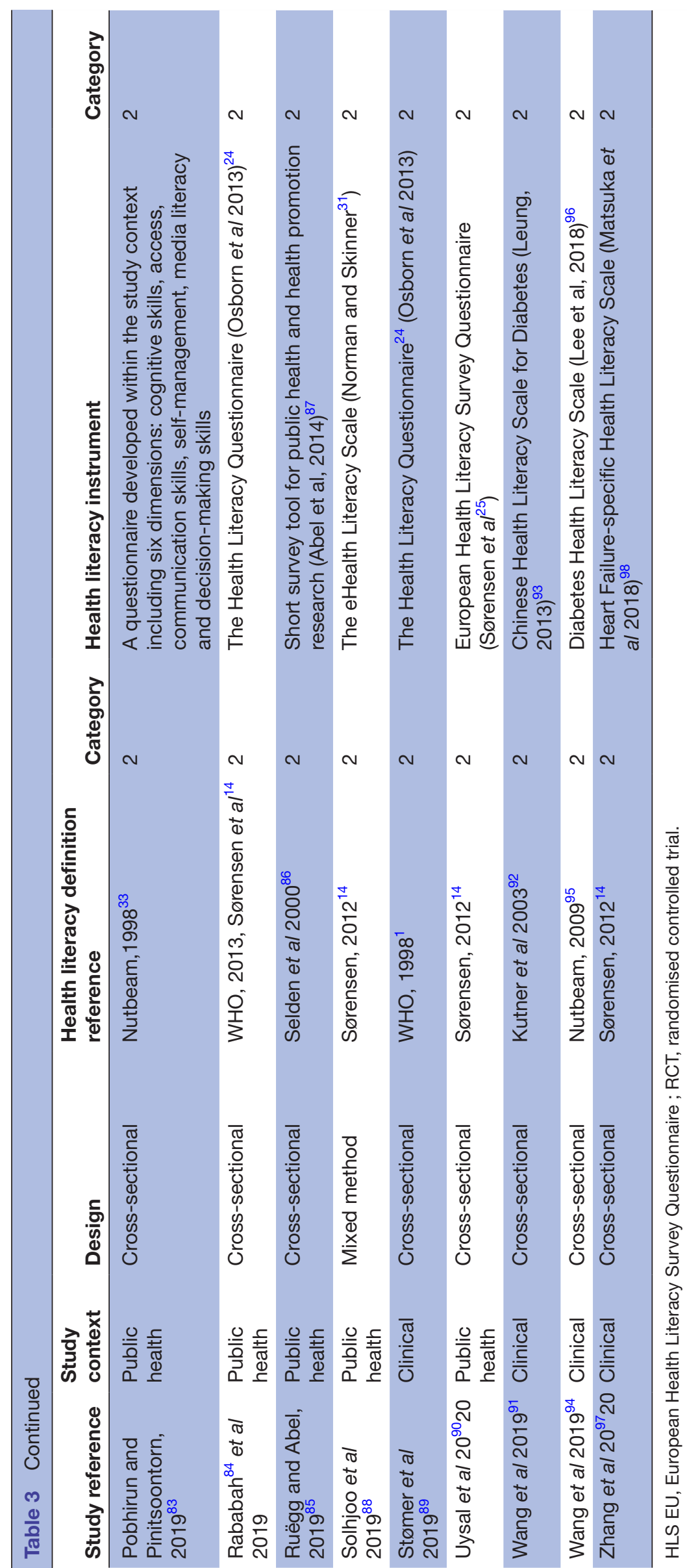

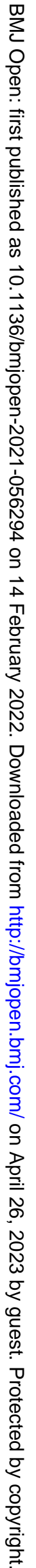


the most cited health literacy definitions. Words in italics are examples of key words considered important in the decision to add the definition to category 1 or category 2. For instance, definitions that described health literacy with terms such as 'knowledge', 'skills' and 'attitude' were referred to category 1 , while definitions with terms like 'appraise' and 'social skills' were referred to category 2.

Regarding the connection between health literacy definitions and instruments in the 79 relevant studies, 41 articles used health literacy definitions and instruments characterised at the same level. Thirty-three of these were in category 2, and 8 were in category 1 (see figure 4 and table 3).

In the remaining 38 studies, there was a disconnect between levels of health literacy definitions and instruments. In all of these, health literacy definitions were from category 2, and all instruments were in category 1 (see table 4).

\section{DISCUSSION}

This systematic review aimed to gain insights into how current research defines and measures health literacy and, in particular, whether studies consistently used definitions and instruments. The high number of articles published in the defined time frame shows that health literacy is of high research interest in both public health and the clinical field in large parts of the world.

We found a large variety of instruments used, and the majority of the included studies (79 out of 120) presented a health literacy definition as part of the study's theoretical background. However, there seems to be an inconsistency between the definitions and the instruments in a significant number of the studies. In nearly half of the studies, health literacy was defined in a broad perspective (including aspects such as social health literacy competence and the ability to process and appraise health information) while using instruments with a more narrow focus (measuring basic skills and knowledge). As a result, almost half of the articles in our review lacked data on the participants' ability to critically appraise health information and their social health literacy competence despite the fact that the authors had stated such aspects to be health literacy. This concern has previously been addressed. Numerous systematic reviews have reported on the diversity of understandings of health literacy and the various use of instruments not aligned to the definitions in current research. ${ }^{16-21}$ However, the current study is, to the best of our knowledge, the first review to systematically investigate the relationship between health literacy definitions and instruments from the perspective of a health literacy model.

The use of instruments that focused on functional health literacy (addressed to category 1), such as Newest Vital Sign and Test of Functional Health Literacy, were predominant in our review. ${ }^{28}{ }^{29}$ This finding corresponds with previous findings. ${ }^{19} 20$ The widespread use of Newest Vital Sign and Test of Functional Health Literacy is justified by the fact that they are screening tools-that is, they are quick, available in an ever-increasing number of languages and can be adapted to different settings. ${ }^{37}$ However, a broad range of skills and tasks covering functional, interactive and critical domains needs to be included in measures of health literacy in order to capture the health literacy definitions used. ${ }^{32}$ In recent years, an increasing number of multidimensional instruments have been developed. In our review, The European Health Literacy Survey Questionnaire and The eHealth Literacy Scale, both addressed to category 2, were the multidimensional instruments most often used. ${ }^{30} 31$ In light of the increased focus on a more multidimensional perspective of health literacy, and the fact that the current review only includes studies from 2019, one could expect a higher use of multidimensional instruments. Instead, they represented only 43 out of 120 instruments.

Clearly, our study highlights the discrepancy between definitions and measurements as well as the narrow focus of health literacy in a large amount of empirical research. An important question to raise is therefore how the findings from this specific study can guide future research strategies to overcome the identified inconsistency. In other words, as most health literacy researchers seem to base their research on a broad understanding of health literacy, what can be done to facilitate an increased use of broad measurements? A first step should be to make researchers aware about the existing mismatch in current research. Furthermore, it seems necessary to develop more instruments that can answer the research questions posed. Despite the high number of instruments, there still seems to be a need for questionnaires in the field of health literacy that capture more multidimensional dimensions besides the functional aspects.

Nutbeam's description of three levels of health literacy inspired the categorisation of definitions and instruments. ${ }^{22}$ Initially, we planned to distinguish among the three levels. However, the line between levels 2 and 3 was challenging to distinguish. Therefore, it was decided to merge the two latter categories. In a recent publication from 2020, Nutbeam has provided a more thorough description of the three levels with a more detailed explanation of how the levels should be understood. ${ }^{38}$ Perhaps, these descriptions would have contributed to a clearer guidance in our work with the categorisation. However, this material was not available at the time of our work and, in general, this situation illustrates the challenge of adapting a theoretical model into practise.

The interpretation of terms used in the definitions and instruments that guided the choice of category also represented some challenges. These were resolved through discussions both in pairs and as a research team. For instance, definitions describing health literacy using terms like knowledge and 'beliefs' were included in category 1, while definitions using terms such as appraise' and 'understand and process' were included in category 2. An interesting finding is that, among the eight studies providing a health literacy definition from category 1 , the 
Table 4 Studies categorised with conflicting levels of health literacy definitions and instruments $(n=38)$

\begin{tabular}{|c|c|c|c|c|c|c|}
\hline Study reference & $\begin{array}{l}\text { Study } \\
\text { context }\end{array}$ & Design & $\begin{array}{l}\text { Health literacy } \\
\text { definition reference }\end{array}$ & Category & $\begin{array}{l}\text { Health literacy } \\
\text { instrument }\end{array}$ & Category \\
\hline $\begin{array}{l}\text { Anderson et al } \\
20^{99} 20\end{array}$ & Clinical & Cross-sectional & $\begin{array}{l}\text { Defined within the study } \\
\text { context (no reference } \\
\text { provided) }\end{array}$ & 2 & $\begin{array}{l}\text { S-TOFHLA (Parker et } \\
\left.a l^{29}\right)\end{array}$ & 1 \\
\hline Avci et al $2019^{100}$ & $\begin{array}{l}\text { Public } \\
\text { health }\end{array}$ & Cross-sectional & $\begin{array}{l}\text { US Department of Health } \\
\text { and Human Services, } \\
2000^{48}\end{array}$ & 2 & $\begin{array}{l}\text { NVS (Weiss et } a l^{28} \text { ) and } \\
\text { REALM (Davis, 1993) }\end{array}$ & 1 \\
\hline $\begin{array}{l}\text { Bonaccorsi et al } \\
2019 \|^{103}\end{array}$ & $\begin{array}{l}\text { Public } \\
\text { health }\end{array}$ & Cross-sectional & Sørensen et al ${ }^{14}$ & 2 & NVS (Weiss et al ${ }^{28}$ ) & 1 \\
\hline $\begin{array}{l}\text { Carducci et al } \\
2019^{104}\end{array}$ & $\begin{array}{l}\text { Public } \\
\text { health }\end{array}$ & Cross-sectional & $\begin{array}{l}\text { Ratzan and Parker, } 2000 \\
\text { Nutbeam, } 2000^{22}\end{array}$ & 2 & $\begin{array}{l}\text { TOFHLA (Parker, } \\
\text { 1995) }\end{array}$ & 1 \\
\hline $\begin{array}{l}\text { de Melo et al } \\
2019^{107}\end{array}$ & Clinical & Cross-sectional & Cavanaugh, $2011^{108}$ & 2 & $\begin{array}{l}\text { Short Test of Functional } \\
\text { Health Literacy in } \\
\text { Adults (Parker et }\left.a\right|^{29} \text { ) }\end{array}$ & 1 \\
\hline Flynn et al $2019^{109}$ & $\begin{array}{l}\text { Public } \\
\text { health }\end{array}$ & Cross-sectional & $\begin{array}{l}\text { American Dental } \\
\text { Association Council, } \\
20^{110} 09\end{array}$ & 2 & $\begin{array}{l}\text { Oral Health Literacy } \\
\text { Adults Questionnaire } \\
\text { (Sistani et al 2014) }^{111}\end{array}$ & 1 \\
\hline Gaikwad, $2019^{112}$ & $\begin{array}{l}\text { Public } \\
\text { health }\end{array}$ & Cross-secttional & $\begin{array}{l}\text { Ratzan and Parker, } \\
2000^{113}\end{array}$ & 2 & $\begin{array}{l}\text { Rapid Estimation } \\
\text { of Adult Literacy in } \\
\text { Dentistry } \\
30 \text {-word version (Lee et } \\
\text { al 2007) }\end{array}$ & 1 \\
\hline Himes et al $2019^{118}$ & $\begin{array}{l}\text { Public } \\
\text { health }\end{array}$ & Cross- sectional & $\begin{array}{l}\text { Institute of Medicine, US, } \\
\text { Committee HL, } 2004^{40}\end{array}$ & 2 & $\begin{array}{l}\text { Chew et al's (2004) set } \\
\text { of brief questions }\end{array}$ & 1 \\
\hline Irvin et al $2019^{119}$ & $\begin{array}{l}\text { Public } \\
\text { health }\end{array}$ & Cross-sectional & Peters et al $2012^{120}$ & 2 & $\begin{array}{l}\text { The Water } \\
\text { Environmental Literacy } \\
\text { Level Scale (Irvin et al } \\
\text { 2019) }\end{array}$ & 1 \\
\hline Kaur et al $2019^{121}$ & $\begin{array}{l}\text { Public } \\
\text { health }\end{array}$ & $\mathrm{RCT}$ & $\begin{array}{l}\text { Healthy People, } 2010 \\
\text { (Oral health) }^{122}\end{array}$ & 2 & $\begin{array}{l}\text { TS-REALD Two-Stage } \\
\text { Rapid Estimate of Adult } \\
\text { Literacy (Stucky et al } \\
\text { 2011) }\end{array}$ & 1 \\
\hline Kim et al $2019^{124}$ & $\begin{array}{l}\text { Public } \\
\text { health }\end{array}$ & Cross-sectional & $\begin{array}{l}\text { Ratzan and Parker, } \\
2000^{113}\end{array}$ & 2 & $\begin{array}{l}\text { Three questions, } \\
\text { each addressing oral, } \\
\text { listening, and written } \\
\text { literacies (no reference) }\end{array}$ & 1 \\
\hline Kim et al $2019^{125}$ & $\begin{array}{l}\text { Public } \\
\text { health }\end{array}$ & Quasi-experimental & $\begin{array}{l}\text { Joint Committee on } \\
\text { National Education } \\
\text { Standards, } 1995^{126}\end{array}$ & 2 & $\begin{array}{l}\text { Knowledge questions } \\
\text { developed in the study } \\
\text { context }\end{array}$ & 1 \\
\hline Kim et al $2019^{127}$ & Clinical & $\mathrm{RCT}$ & $\begin{array}{l}\text { Institute of Medicine, US, } \\
\text { Committee HL, } 2004^{40}\end{array}$ & 2 & $\begin{array}{l}\text { S-TOFHLA (Parker et } \\
\left.\left.a\right|^{29}\right)\end{array}$ & 1 \\
\hline Kino et al $2020^{128}$ & $\begin{array}{l}\text { Public } \\
\text { health }\end{array}$ & Cross-sectional & Inst of Medicine, $2004^{40}$ & 2 & $\begin{array}{l}\text { Three indicators of } \mathrm{HL} \\
\left(\text { Haun et } a l^{20}\right)\end{array}$ & 1 \\
\hline
\end{tabular}


Table 4 Continued

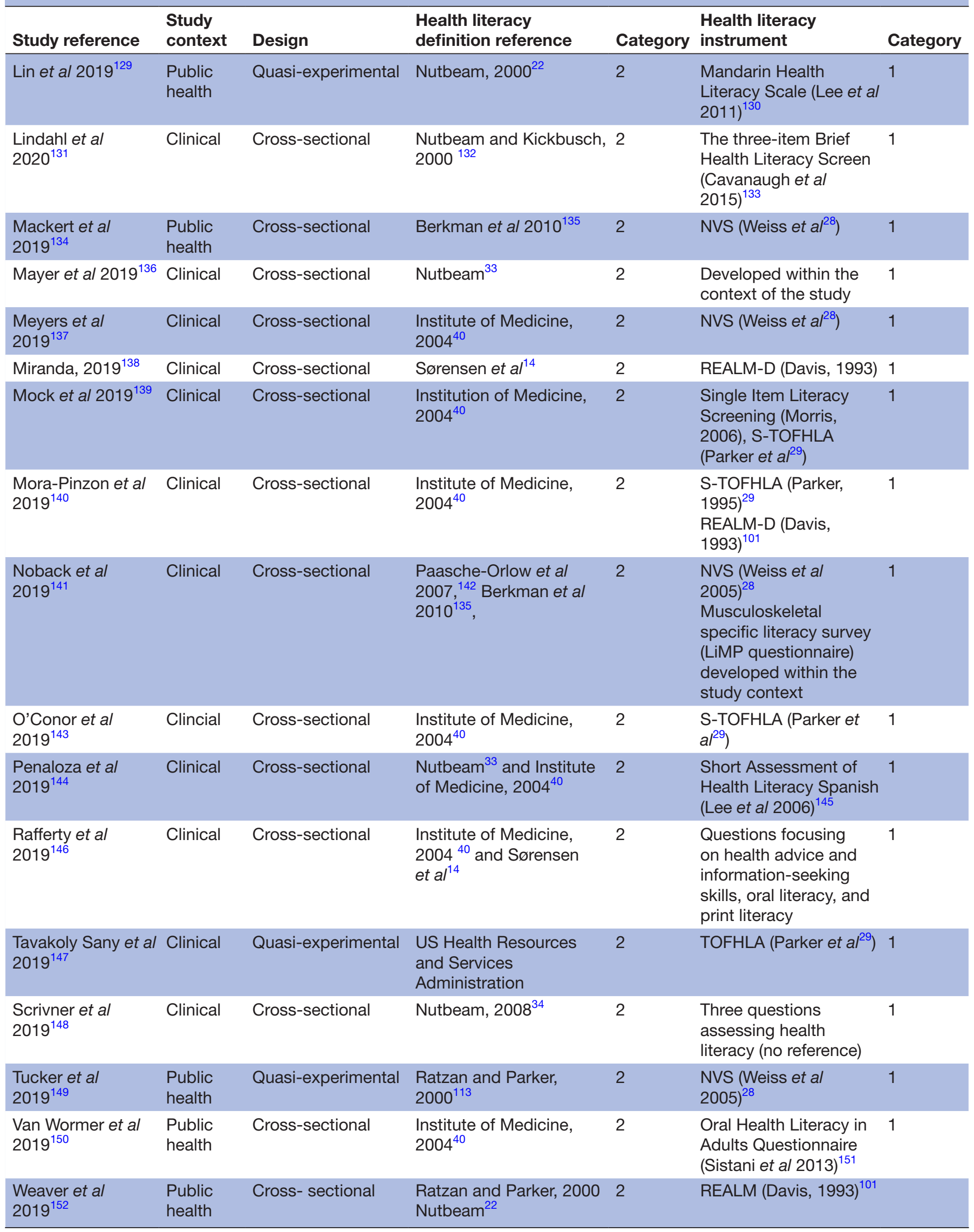


Table 4 Continued

\begin{tabular}{|c|c|c|c|c|c|c|}
\hline Study reference & $\begin{array}{l}\text { Study } \\
\text { context }\end{array}$ & Design & $\begin{array}{l}\text { Health literacy } \\
\text { definition reference }\end{array}$ & Category & $\begin{array}{l}\text { Health literacy } \\
\text { instrument }\end{array}$ & Category \\
\hline Zhong et al $2020^{153}$ & Clinical & Cross-sectional & Kindig, $2004^{154}$ & 2 & $\begin{array}{l}\text { NVS (Weiss et al } \\
2005)^{28}\end{array}$ & 1 \\
\hline $\begin{array}{l}\text { Williams et al } \\
2019^{155}\end{array}$ & Clinical & Cross-sectional & $\begin{array}{l}\text { Institute of Medicine, } \\
2004^{40}\end{array}$ & 2 & $\begin{array}{l}\text { NVS (Weiss et al } \\
2005)^{28}\end{array}$ & 1 \\
\hline $\begin{array}{l}\text { Winokur et al } \\
2019^{156}\end{array}$ & Clincial & Cross-sectional & Morrison et al $2013^{157}$ & 2 & $\begin{array}{l}\text { NVS (Weiss et al } \\
2005)^{28}\end{array}$ & 1 \\
\hline
\end{tabular}

NVS, Newest Vital Sign; RCT, randomised controlled trial; REALM, Rapid Estimate of Adult Literacy in Medicine; REALM-D, Rapid Estimate of Adult Literacy, Dutch Version; S-TOFHLA, Short Test of Functional Health Literacy in Adults; TOFHLA, Test of Functional Health Literacy in Adults.

majority $(n=5)$ were in the context of mental health. The predominant reference in these studies was the definition provided by Jorm and colleagues, who, unlike others, defined health literacy as being linked to beliefs and 'attitudes'. ${ }^{35}$ Whether these terms are more closely linked to mental health literacy challenges, compared with other more 'physical' health literacy issues, is not clear but would be interesting for further investigation.

Another aspect worth noting is that we discovered that many publications did not cite the primary source of the health literacy definitions but instead referred to secondary sources (other researchers presenting definitions of health literacy). Referring to the original sources should be the first choice and would perhaps make it easier for readers to recognise the definition's affiliation.

The present study has some limitations. First, this study was designed to analyse and describe health literacy research in two randomly selected months. This period may not be representative of health literacy research in general. However, a large number of health literacy studies are published every year. A random selection can therefore give a good picture of health literacy research. Second, we did not conduct a quality assessment screening of the included studies. This was considered less relevant for the current study as the aim of the current study was to explore connections between health literacy definitions and instruments rather than to assess methodology. Furthermore, searches were limited to the English language only. It is possible that similar studies may have been published in languages other than English.

The current review included only quantitative measurements. However, qualitative approaches might provide valuable and more in-depth insights into the field. For future research, it would be interesting to also explore how qualitative research links health literacy definitions to the research questions posed.

\section{CONCLUSION}

There seems to be an inconsistency between the definitions and the instruments used in a significant part of current health literacy research. This situation raises the risk of missing information about health literacy that was considered to be important in the initial understanding of the concept recognised in the studies. This gap should be taken into consideration in future health literacy research. We hope our work contributes to making explicit where the problem might be rooted and that it can be useful in the discussion about strategies for moving forward to better align health literacy measurement with definitions of health literacy.

\section{Author affiliations}

${ }^{1}$ Department of Quality and Health Technology, University of Stavanger, Stavanger, Norway

${ }^{2}$ Faculty of Health Sciences, VID Specialized University, Oslo, Akershus, Norway

${ }^{3}$ Department of Interdisciplinary Health Sciences, University of Oslo, Oslo, Norway ${ }^{4}$ Department of Transplantation Medicine, Oslo University Hospital Rikshospitalet, Oslo, Norway

${ }^{5}$ Department of Behavioural Sciences in Medicine, University of Oslo, Oslo, Norway

${ }^{6}$ Lovisenberg Diaconal University College, Oslo, Akershus, Norway

${ }^{7}$ Lovisenberg Diakonale Hospital, Oslo, Norway

${ }^{8}$ Faculty of Health Scienes, Oslo Metropolitan University, Oslo, Norway ${ }^{9}$ Department of Health and Nursing Sciences, University of Agder, Kristiansand, Norway

Contributors $\mathrm{KHU}, \mathrm{MHA}$ and AKW initiated the project and wrote and revised the manuscript. KHU led the project. KHU, MAH, AKW, SH, CRB and MHL designed the study, selected the articles and extracted the data. All authors contributed to drafting the manuscript and met authorship criteria. KHU had full responsibility for the work and the conduct of the study, had access to the data, and controlled the decision to publish.

Funding The Centre for Advanced Study in Oslo, Norway, funded and hosted our research project, The Body in Translation: Historicising and Reinventing Medical Humanities and Knowledge Translation, during the 2019/2020 academic year.

Competing interests None declared.

Patient consent for publication Not applicable.

Ethics approval This study does not involve human participants.

Provenance and peer review Not commissioned; externally peer reviewed.

Data availability statement Data are available upon reasonable request.

Supplemental material This content has been supplied by the author(s). It has not been vetted by BMJ Publishing Group Limited (BMJ) and may not have been peer-reviewed. Any opinions or recommendations discussed are solely those of the author(s) and are not endorsed by BMJ. BMJ disclaims all liability and responsibility arising from any reliance placed on the content. Where the content includes any translated material, BMJ does not warrant the accuracy and reliability of the translations (including but not limited to local regulations, clinical guidelines, terminology, drug names and drug dosages), and is not responsible for any error and/or omissions arising from translation and adaptation or otherwise.

Open access This is an open access article distributed in accordance with the Creative Commons Attribution Non Commercial (CC BY-NC 4.0) license, which 
permits others to distribute, remix, adapt, build upon this work non-commercially, and license their derivative works on different terms, provided the original work is properly cited, appropriate credit is given, any changes made indicated, and the use is non-commercial. See: http://creativecommons.org/licenses/by-nc/4.0/.

\section{ORCID iD}

Kristin Hjorthaug Urstad http://orcid.org/0000-0002-8830-4564

\section{REFERENCES}

1 WHO. Health promotion glossary. Geneva: WHO, 1998.

2 Visscher BB, Steunenberg B, Heijmans M, et al. Evidence on the effectiveness of health literacy interventions in the EU: a systematic review. BMC Public Health 2018;18:1414.

3 Mitchell SE, Sadikova E, Jack BW, et al. Health literacy and 30-day postdischarge Hospital utilization. J Health Commun 2012;17:325-38.

4 Baker DW, Gazmararian JA, Williams MV, et al. Functional health literacy and the risk of hospital admission among Medicare managed care enrollees. Am J Public Health 2002;92:1278-83.

5 Adams RJ, Piantadosi C, Ettridge K, et al. Functional health literacy mediates the relationship between socio-economic status, perceptions and lifestyle behaviors related to cancer risk in an Australian population. Patient Educ Couns 2013;91:206-12.

6 Thomson MD, Hoffman-Goetz L. Application of the health literacy framework to diet-related cancer prevention conversations of older immigrant women to Canada. Health Promot Int 2012;27:33-44

7 Jovanić M, Zdravković M, Stanisavljević D, et al. Exploring the importance of health literacy for the quality of life in patients with heart failure. Int J Environ Res Public Health 2018;15:1761.

8 O'Hara J, McPhee C, Dodson S, et al. Barriers to breast cancer screening among diverse cultural groups in Melbourne, Australia. Int J Environ Res Public Health 2018;15:1677.

9 Chen J-Z, Hsu H-C, Tung H-J, et al. Effects of health literacy to selfefficacy and preventive care utilization among older adults. Geriatr Gerontol Int 2013;13:70-6.

10 Olesen K, F Reynheim AL, Joensen L, et al. Higher health literacy is associated with better glycemic control in adults with type 1 diabetes: a cohort study among 1399 Danes. BMJ Open Diabetes Res Care 2017;5:e000437.

11 Bostock S, Steptoe A. Association between low functional health literacy and mortality in older adults: longitudinal cohort study. $B M J$ 2012;344:e1602.

12 Peterson PN, Shetterly SM, Clarke CL. Low health literacy is associated with increased risk of mortality in patients with heart failure. Circulation 2009;120:749

13 Peterson PN, Shetterly SM, Clarke CL, et al. Health literacy and outcomes among patients with heart failure. JAMA 2011;305:1695-701.

14 Sørensen K, Van den Broucke S, Fullam J, et al. Health literacy and public health: a systematic review and integration of definitions and models. BMC Public Health 2012;12:80

15 Parker RM, Ratzan S. Re-enforce, not re-define health literacymoving forward with healthHealth literacy 2.0. J Health Commun 2019;24:923-5.

16 Malloy-Weir LJ, Charles C, Gafni A, et al. A review of health literacy: definitions, interpretations, and implications for policy initiatives. $J$ Public Health Policy 2016;37:334-52.

17 Liu C, Wang D, Liu C, et al. What is the meaning of health literacy? A systematic review and qualitative synthesis. Fam Med Community Health 2020;8:e000351.

18 Parnell TA, Stichler JF, Barton AJ, et al. A concept analysis of health literacy. Nurs Forum 2019;54:315-27.

19 O Neill B, Goncalves D, Ricci-Cabello I, et al. An overview of self-administered health literacy instruments. PLoS One 2014;9:e109110.

20 Haun JN, Valerio MA, McCormack LA, et al. Health literacy measurement: an inventory and descriptive summary of 51 instruments. J Health Commun 2014;19:302-33.

21 Nguyen TH, Park H, Han H-R, et al. State of the science of health literacy measures: validity implications for minority populations. Patient Educ Couns 2015:1512 doi:10.1016/j.pec.2015.07.013

22 Nutbeam D. Health literacy as a public health goal: a challenge for contemporary health education and communication strategies into the 21st century. Health Promot Int 2000;15:259-67.

23 Nguyen TH, Paasche-Orlow MK, McCormack LA. The state of the science of health literacy measurement. Stud Health Technol Inform 2017;:240:189-203.

24 Osborne RH, Batterham RW, Elsworth GR, et al. The grounded psychometric development and initial validation of the health literacy questionnaire (HLQ). BMC Public Health 2013;13:658.
25 Sørensen K, Van den Broucke S, Pelikan JM, et al. Measuring health literacy in populations: illuminating the design and development process of the European health literacy survey questionnaire (HLSEU-Q). BMC Public Health 2013;13:948.

26 Page MJ, McKenzie JE, Bossuyt PM, et al. The PRISMA 2020 statement: an updated guideline for reporting systematic reviews. BMJ 2021;372:n71.

27 Cataloguing-in-Publication Data International statistical classification of diseases and related health problems. - 10th revision, edition 2010. $3 \mathrm{v}$.

28 Weiss BD, Mays MZ, Martz W, et al. Quick assessment of literacy in primary care: the newest vital sign. Ann Fam Med 2005:3:514-22.

29 Parker RM, Baker DW, Williams MV, et al. The test of functional health literacy in adults: a new instrument for measuring patients' literacy skills. J Gen Intern Med 1995;10:537-41.

30 Sørensen K, Van den Broucke S, Pelikan JM, et al. Measuring health literacy in populations: illuminating the design and development process of the European health literacy survey questionnaire (HLSEU-Q). BMC Public Health 2013;13:948.

31 Norman CD, Skinner HA. eHEALS: the eHealth literacy scale. J Med Internet Res 2006;8:e27.

32 Nutbeam D. Defining, measuring and improving health literacy. Health evaluation and promotion 2015;42:450-6.

33 Nutbeam D. Health promotion glossary. Health Promot Int 1998;13:349-64. Volume.

34 Nutbeam D. The evolving concept of health literacy. Soc Sci Med 2008;67:2072-8.

35 Jorm AF, Korten AE, Jacomb PA, et al. "Mental health literacy": a survey of the public's ability to recognise mental disorders and their beliefs about the effectiveness of treatment. Med J Aust 1997;166:182-6.

36 Jorm AF. Mental health literacy: empowering the community to take action for better mental health. Am Psychol 2012;67:231-43.

37 Marques SRL, Lemos SMA. Instrumentos de avaliação do letramento em saúde: revisão de literatura. Audiology Communication Research 2017;22:e1757.

38 Nutbeam D, Muscat DM. Advancing health literacy interventions. Stud Health Technol Inform 2020;269:115-27.

39 American Medical Association. Health literacy: report of the Council on scientific affairs. AD hoc Committee on health literacy for the Council on scientific Affairs, American Medical association. JAMA 1999;281:552-7.

40 Institute of Medicine. Health literacy: a prescription to end confusion. Washington DC: National Academies Press, 2004.

41 Chehuen Neto JA, Costa LA, Estevanin GM, et al. Functional health literacy in chronic cardiovascular patients. Cien Saude Colet 2019;24:1121-32

42 Clough BA, Nazareth SM, Casey LM. Making the grade: a pilot investigation of an e-intervention to increase mental health literacy and help-seeking intentions among international university students. Br J Guid Counc 2020;48:347-59.

43 O'Connor M, Casey L. The mental health literacy scale (MHLS): a new scale-based measure of mental health literacy. Psychiatry Res 2015;229:511-6.

44 Clough BA, Nazareth SM, Day JJ, et al. A comparison of mental health literacy, attitudes, and help-seeking intentions among domestic and international tertiary students. Br J Guid Counc 2019;47:123-35.

45 Johnco C, Salloum A, McBride NM, et al. Mental health literacy, treatment preferences, and barriers in Salvadorian parents. Int $J$ Ment Health 2019;48:139-64.

46 Gray KM. From content knowledge to community change: a review of representations of environmental health literacy. Int J Environ Res Public Health 2018;15:466.

47 Nye R, Robinia K. The effect of a community based educational intervention on oral health knowledge levels of adult caregivers of young children in the rural upper Peninsula of Michigan. $J$ Community Health Nurs 2019;36:188-98.

48 Department of Health and Human Services. Office of disease prevention and health promotion. No. 21 oral health: terminology. Healthy People 2010;2010. [Epub ahead of print: Retrieved from] https://healthypeople.gov/2010/Document/HTML/Volume2/21Oral. htm

49 Waldmann T, Staiger T, Oexle N, et al. Mental health literacy and help-seeking among unemployed people with mental health problems. J Ment Health 2020;29:270-6.

50 Wilson CJ, Deane FP, Ciarrochi J, et al. Measuring help-seeking intentions: properties of the general help-seeking questionnaire. Canadian Journal of Counselling and Psychotherapy 2005;39:15-28.

51 Williston SK, Bramande EA, Vogt DS, et al. An examination of the roles of mental health literacy, treatment-seeking stigma, and 
perceived need for care in female veterans' service use. Psychiatr Serv 2020;71:144-50.

52 An J-Y, Moon H, Cha S. Health literacy, depression, and stress among Chinese immigrants in South Korea. Public Health Nurs 2019;36:603-14.

53 Chew LD, Bradley KA, Boyko EJ. Brief questions to identify patients with inadequate health literacy. Fam Med 2004;36:588-94.

54 Azizi N, Karimy M, Abedini R, et al. Development and validation of the health literacy scale for workers. Int J Occup Environ Med 2019:10:30-9.

55 Brandstetter S, Atzendorf J, Seelbach-Göbel B, et al. Sociodemographic factors associated with health literacy in a large sample of mothers of newborn children: cross-sectional findings from the KUNO-Kids birth cohort study. Eur J Pediatr 2020;179:165-9.

56 Degan TJ, Kelly PJ, Robinson LD, et al. Health literacy in people living with mental illness: a latent profile analysis. Psychiatry Res 2019;280:112499 https://www.sciencedirect.com/science/article/ pii/S0165178119307140

57 Eo Y-S, Kim J-S. Associations of health belief and health literacy with Pap smear practice among Asian immigrant women. Eur J Oncol Nurs 2019;42:63-8.

58 An J, Yang SJ. Development of a health literacy assessment scale for Asian immigrant women in South Korea. J Korean Acad Community Health Nurs 2015;26:330-41.

59 Ernsting C, Stühmann LM, Dombrowski SU, et al. Associations of health APP use and perceived effectiveness in people with cardiovascular diseases and diabetes: population-based survey. JMIR Mhealth Uhealth 2019;7:e12179.

60 Erunal M, Ozkaya B, Mert H, et al. Investigation of health literacy levels of nursing students and affecting factors. International Journal of Caring Sciences 2019;12:270-9.

6160 Okyay P, Abacigil F, Harlak H. Turkish health literacy scales reliability and validity study. 1. edition. Ankara: Saglik Bakanligi Yayin No, 2016: 43-60.

62 Evans A-Y, Anthony E, Gabriel G. Comprehensive health literacy among undergraduates: a Ghanaian University-Based crosssectional study. Health Lit Res Pract 2019;3:e227-37.

63 Fernández-Gutiérrez M, Bas-Sarmiento P, Poza-Méndez M. Effect of an mHealth intervention to improve health literacy in immigrant populations: a quasi-experimental study. Comput Inform Nurs 2019;37:142-50.

64 Goto E, Ishikawa H, Okuhara T, et al. Relationship of health literacy with utilization of health-care services in a general Japanese population. Prev Med Rep 2019;14:100811.

65 Guclu OA, Demirci H, Ocakoglu G, et al. Relationship of pneumococcal and influenza vaccination frequency with health literacy in the rural population in turkey. Vaccine 2019;37:6617-23.

66 Güner MD, Ekmekci PE. A survey study evaluating and comparing the health literacy knowledge and communication skills used by nurses and physicians. INQUIRY 2019;56:004695801986583.

$67 \mathrm{Hu}$ A, Yang XY. Is College education an equalizer for social disparities in health literacy? A case study in Shanghai, China. Glob Health Promot 2019;26:62-70.

68 Jordan JE, Buchbinder R, Briggs AM, et al. The health literacy management scale (HeLMS): a measure of an individual's capacity to seek, understand and use health information within the healthcare setting. Patient Educ Couns 2013;91:228-35.

69 Indino K, Sharp R, Esterman A. The effect of health literacy on treatment adherence in maintenance haemodialysis patients: a cross-sectional study. Renal Society of Australasia Journal 2019:15:11-18 https://search.informit.org/doi/

70 Kaper MS, Winter AFde, Bevilacqua R, et al. Positive outcomes of a comprehensive health literacy communication training for health professionals in three European countries: a multi-centre prepost intervention study. Int J Environ Res Public Health 2019;16. doi:10.3390/ijerph16203923. [Epub ahead of print: 1510 2019].

71 Kwan B, Frankish J, Rootman I, et al. The Development and Validation of Measures of "Health Literacy" in Different Populations. UBC Institute of Health Promotion Research and University of Victoria Community Health Promotion Research;2006.

72 Kobayashi R, Ishizaki M. Examining the interaction between medical information seeking online and understanding: exploratory study. JMIR Cancer 2019;5:e13240.

73 Lim BT, Huang Y-J, Shepherd HL, et al. Health literacy and cancer care coordination in Chinese migrant patients and their carers: a cross-sectional survey. Psychooncology 2019;28:1048-55.

74 Logullo P, Torloni MR, de O C Latorraca C, et al. The Brazilian Portuguese version of the discern instrument: translation procedures and psychometric properties. Value Health Reg Issues 2019;20:172-9.
75 Apolinario D, Braga RdeCOP, Magaldi RM, et al. Short assessment of health literacy for Portuguese-speaking adults. Rev Saude Publica 2012;46:702-11.

$76 \mathrm{Lu} \mathrm{M}, \mathrm{Xia} \mathrm{H}, \mathrm{Ma}$ J, et al. Relationship between adherence to secondary prevention and health literacy, self-efficacy and disease knowledge among patients with coronary artery disease in China. Eur J Cardiovasc Nurs 2020;19:230-7.

77 Lu M, Ma J, Lin Y, et al. Relationship between patient's health literacy and adherence to coronary heart disease secondary prevention measures. J Clin Nurs 2019;28:2833-43.

$78 \mathrm{Ma}$ Z, Wu M. The psychometric properties of the Chinese eHealth literacy scale (C-eHEALS) in a Chinese rural population: crosssectional validation study. J Med Internet Res 2019;21:e15720.

79 Nokes KM, Reyes DM. Do brief educational sessions increase electronic health literacy of low-income persons living with HIV/ AIDS? Comput Inform Nurs 2019;37:315-20.

$80 \mathrm{Oh} \mathrm{HJ}$, Lee H. When do people verify and share health Rumors on social media? the effects of message importance, health anxiety, and health literacy. J Health Commun 2019;24:837-47.

81 Oliffe JL, McCreary DR, Black N, et al. Canadian men's health literacy: a nationally representative study. Health Promot Pract 2020;21:993-1003.

82 Peerson A, Saunders M. In search of a gender lens.. International Journal of Men's Health. 2011;2.

83 Pobhirun T, Pinitsoontorn S. The association between health literacy and pesticide use behaviors among sweet corn farmers in the PAK Chong district of Thailand: a cross-sectional study. F1000Res 2019;8:448.

84 Rababah JA, Al-Hammouri MM, Drew BL, et al. Health literacy: exploring disparities among college students. BMC Public Health 2019:19:1401.

85 Rüegg R, Abel T. The relationship between health literacy and health outcomes among male young adults: exploring confounding effects using decomposition analysis. Int J Public Health 2019;64:535-45.

86 Selden CR, Zorn M, Ratzan S, et alSelden CR, ed. Health literacy. Bethesda: National Library of Medicine, 2000.

87 Abel T, Hofmann K, Ackermann S, et al. Health literacy among young adults: a short survey tool for public health and health promotion research. Health Promot Int 2015;30:725-35.

88 Solhjoo N, Naghshineh N, Fahimnia F. Veterinarians' information Prescription and Clients' eHealth Literacy. J Can Health Libr Assoc 2019;40:32-44.

89 Stømer UE, Gøransson LG, Wahl AK, et al. A cross-sectional study of health literacy in patients with chronic kidney disease: associations with demographic and clinical variables. Nurs Open 2019;6:1481-90

90 Uysal N, Ceylan E, Koç A. Health literacy level and influencing factors in university students. Health Soc Care Community 2020;28:505-11.

91 Wang X, Gao H, Xu H. Cluster analysis of unhealthy lifestyles among elderly adults with prediabetes: a cross-sectional study in rural China. Diabetes Ther 2019;10:1935-48.

92 Kutner ME, Greenberg E, Jin Y, et al. The health literacy of America's adults: results from the 2003 national assessment of adult literacy (NCES 2006-483). National Cent Educ Stat 2006;39:685-7.

93 Leung AYM, Lou VWQ, Cheung MKT, et al. Development and validation of Chinese health literacy scale for diabetes. J Clin Nurs 2013;22:2090-9.

94 Wang R-H, Hsu H-C, Chen S-Y, et al. Modeling patient empowerment and health literacy to glycemic control in insulintreated patients: a prospective study. Patient Educ Couns 2019;102:1336-41.

95 Nutbeam D. Defining and measuring health literacy: what can we learn from literacy studies? Int J Public Health 2009;54:303-5.

96 Lee E-H, Lee YW, Lee K-W, et al. A new comprehensive diabetes health literacy scale: development and psychometric evaluation. Int J Nurs Stud 2018;88:1-8.

97 Zhang J, Gilmour S, Liu Y, et al. Effect of health literacy on quality of life among patients with chronic heart failure in China. Qual Life Res 2020;29:453-61.

98 Matsuoka S, Kato N, Kayane T, et al. Development and validation of a heart Failure-Specific health literacy scale. J Cardiovasc Nurs 2016;31:131-9.

99 Anderson AN, Haardörfer R, Holstad MM, et al. A path analysis of patient and Social-Level factors on health literacy and retention in care among African Americans living with HIV. AIDS Behav 2020:24:1124-32

100 Avci G, Kordovski VM, Woods SP. A preliminary study of health literacy in an ethnically diverse university sample. J Racial Ethn Health Disparities 2019;6:182-8. 
101 Davis TC, Long SW, Jackson RH, et al. Rapid estimate of adult literacy in medicine: a shortened screening instrument. Fam Med 1993;25:391-6.

102 Bonaccorsi G, Pieralli F, Innocenti M, et al. Non-Familial paid caregivers as potential flu carriers and cause of spread: the primary prevention of flu measured through their adhesion to flu vaccination campaigns-A Florentine experience. Hum Vaccin Immunother 2019;15:2416-22.

103 Bonaccorsi G, Pieralli F, Innocenti M, et al. Health literacy among non-familial caregivers of older adults: a study conducted in Tuscany (Italy). Int J Environ Res Public Health 2019;16:3771.

104 Carducci A, Fiore M, Azara A, et al. Environment and health: risk perception and its determinants among Italian university students. Sci Total Environ 2019;691:1162-72.

105 Chen S-Y, Hsu H-C, Wang R-H, et al. Glycemic control in insulintreated patients with type 2 diabetes: Empowerment perceptions and diabetes distress as important determinants. Biol Res Nurs 2019;21:182-9.

106 Lee Y-J, Shin S-J, Wang R-H. Pathways of empowerment perceptions, health literacy, self-efficacy, and self-care behaviors to glycemic control in patients with type 2 diabetes mellitus, patient education and counseling, volume 99, 2016: Pages 287-294, ISSN-3991. https://www.sciencedirect.com/science/article/pii/ S0738399115300586

107 de Melo Bezerra JN, de Oliveira Lessa SR, Francisco do Ó M, et al. De Oliveira Tito Borba AK. health literacy of individuals undergoing dialysis therapy. Texto \& Contexto Enfermagem 2019;28:1-13.

108 Cavanaugh KL. Health literacy in diabetes care: explanation, evidence and equipment. Diabetes Manag 2011;1:191-199.

109 Flynn PM, John MT, Sistani MMN. Confirmation of the unidimensional structure of the oral health literacy adults questionnaire. Int Dent J 2019;69:207-13.

110 American Dental Association. Health literacy in dentistry action plan 2010-2015. Chicago IL: ADA, 2009.

111 Naghibi Sistani MM, Montazeri A, Yazdani R, et al. New oral health literacy instrument for public health: development and pilot testing. $J$ Invest Clin Dent 2014;5:313-21.

112 Gaikwad RN. Quantifying OHIP in the context with oral health literacy in rural and urban population. J Contemp Dent Pract 2019;20:834-7.

113 Ratzan SC, Parker RM. Introduction. In: Selden CR, Zorn M, Ratzan SC, eds. National library of medicine current bibliographies in medicine:Health literacy. NLM Pub. No. CBM. Bethesda: MD, 2000: 2000-1.

114 Lee JY, Rozier RG, Lee S-YD, et al. Development of a word recognition instrument to test health literacy in dentistry: the REALD-30--a brief communication. J Public Health Dent 2007;67:94-8.

115 Güner MD, Ekmekci PE. A survey study evaluating and comparing the health literacy knowledge and communication skills used by nurses and physicians. Inquiry 2019;56:004695801986583.

116 Han H-R, Kim K, Cudjoe J, et al. Familiarity, navigation, and comprehension: key dimensions of health literacy in Pap test use among Korean American women. $J$ Health Commun 2019;24:585-91.

117 Han H-R, Huh B, Kim MT, et al. Development and validation of the assessment of health literacy in breast and cervical cancer screening. J Health Commun 2014;19 Suppl 2:267-84.

118 Himes DO, Davis SH, Lassetter JH, et al. Does family communication matter? exploring knowledge of breast cancer genetics in cancer families. J Community Genet 2019;10:481-7.

119 Irvin VL, Rohlman D, Vaughan A, et al. Development and validation of an environmental health literacy assessment screening tool for domestic well owners: the water environmental literacy level scale (wells). Int J Environ Res Public Health 2019;16. doi:10.3390/ ijerph16050881. [Epub ahead of print: 1103 2019].

120 Peters E. Beyond comprehension: the role of numeracy in judgments and decisions. Current Directions in Psychological Science 2012;21:31-5.

121 Kaur N, Kandelman D, Potvin L. Effectiveness of "Safeguard Your Smile," an oral health literacy intervention, on oral hygiene self-care behaviour among Punjabi immigrants:A randomized controlled trial. Can J Dent Hyg 2019;53:23-32.

122 people H. Vol. II: Oral Health. Washington, DC:US Government Printing Office 2010;2000.

123 Stucky BD, Lee JY, Lee S-YD, et al. Development of the two-stage rapid estimate of adult literacy in dentistry. Community Dent Oral Epidemiol 2011;39:474-80.

$124 \mathrm{Kim} \mathrm{K}, \mathrm{Han} \mathrm{H}-\mathrm{R}$. The association between health literacy and breast and cervical cancer screening behaviors: findings from the behavioral risk factor surveillance system. Nurs Res 2019;68:177-88.

125 Kim S-W, Park W-Y, Jhon M, et al. Physical health literacy and health-related behaviors in patients with psychosis. Clin Psychopharmacol Neurosci 2019;17:279-87.

126 Joint Committee on National Health Education Standards. National health education standards: achieving health literacy. Reston, VA: Association for the advancement of health education;; 1995.

$127 \mathrm{Kim} \mathrm{SH}$, Utz S. Effectiveness of a social Media-Based, health Literacy-Sensitive diabetes self-management intervention: a randomized controlled trial. J Nurs Scholarsh 2019;51:661-9.

128 Kino S, Kawachi I. Can health literacy boost health services utilization in the context of expanded access to health insurance? Health Educ Behav 2020;47:134-42.

129 Lin S-C, Chen I-J, Yu W-R, et al. Effect of a community-based participatory health literacy program on health behaviors and health empowerment among community-dwelling older adults: a quasiexperimental study. Geriatr Nurs 2019;40:494-501.

130 Tsai T-I, Lee S-YD, Tsai Y-W, et al. Methodology and validation of health literacy scale development in Taiwan. $J$ Health Commun 2011;16:50-61.

131 Lindahl $\mathrm{B}$, Norberg $\mathrm{M}$, Johansson $\mathrm{H}$, et al. Health literacy is independently and inversely associated with carotid artery plaques and cardiovascular risk. Eur J Prev Cardiol 2020;27:209-15.

132 Nutbeam D, Don Nutbeam IK. Advancing health literacy: a global challenge for the 21st century. Health Promot Int 2000;15:183-4.

133 Cavanaugh KL, Osborn CY, Tentori F, et al. Performance of a brief survey to assess health literacy in patients receiving hemodialysis. Clin Kidney J 2015;8:462-8.

134 Mackert M, Mabry-Flynn A, Donovan EE, et al. Health literacy and perceptions of stigma. J Health Commun 2019;24:856-64.

135 Berkman ND, Davis TC, McCormack L. Health literacy: what is it? $J$ Health Commun 2010;15 Suppl 2:9-19.

136 Mayer S, Spickschen J, Stein KV, et al. The societal costs of chronic pain and its determinants: the case of Austria. PLoS One 2019;14:e0213889.

137 Meyers N, Glick AF, Mendelsohn AL, et al. Parents' use of technologies for health management: a health literacy perspective. Acad Pediatr 2020;20:23-30.

138 Miranda R, Meeks KAC, Snijder MB, et al. Health literacy and hypertension outcomes in a multi-ethnic population: the HELIUS study. Eur J Public Health 2020;30:516-21.

139 Mock MS, Sethares KA. Concurrent validity and acceptability of health literacy measures of adults hospitalized with heart failure. Appl Nurs Res 2019;46:50-6.

140 Mora-Pinzon MC, Chrischilles EA, Greenlee RT, et al. Variation in coordination of care reported by breast cancer patients according to health literacy. Support Care Cancer 2019;27:857-65.

141 Noback PC, Seetharaman M, Tantigate D, et al. Musculoskeletal health literacy, pain Catastrophization, and sleep quality: effect on functional disability scores. J Surg Orthop Adv 2019;28:144-9.

142 Paasche-Orlow MK, Wolf MS. The causal pathways linking health literacy to health outcomes. Am J Health Behav 2007;31 Suppl $1: 19-26$.

143 O'Conor R, Muellers K, Arvanitis M, et al. Effects of health literacy and cognitive abilities on COPD self-management behaviors: a prospective cohort study. Respir Med 2019;160:105630.

144 Penaloza R, Navarro JI, Jolly PE, et al. Health literacy and knowledge related to tuberculosis among outpatients at a referral hospital in Lima, Peru. Res Rep Trop Med 2019;10:1-10.

145 Lee S-YD, Bender DE, Ruiz RE, et al. Development of an easy-to-use Spanish health literacy test. Health Serv Res 2006;41:060720074824046-???.

146 Rafferty AP, Winterbauer NL, Luo H, et al. Diabetes self-care and clinical care among adults with low health literacy. J Public Health Manag Pract 2021;27:144-53.

147 Tavakoly Sany SB, Peyman N, Zadehahmad Z, et al. Effect of educational interventions on health literacy in patients with heart failure. Int J Health Promot Educ 2019;57:23-36.

148 Scrivner B, Szaflarski M, Baker EH, et al. Health literacy and quality of life in patients with treatment-resistant epilepsy. Epilepsy Behav 2019;99:106480.

149 Tucker CM, Kang S, Ukonu NA, et al. A culturally sensitive ChurchBased Health-Smart intervention for increasing health literacy and health-promoting behaviors among black adult Churchgoers. $J$ Health Care Poor Underserved 2019;30:80-101.

150 VanWormer JJ, Tambe SR, Acharya A. Oral health literacy and outcomes in rural Wisconsin adults. J Rural Health 2019;35:12-21.

151 Naghibi Sistani MM, Montazeri A, Yazdani R, et al. New oral health literacy instrument for public health: development and pilot testing. J Investig Clin Dent 2014;5:313-21. 
152 Weaver SB, Maneno M, Chijioke P, et al. Factors associated with health literacy and medication adherence in an urban community. $\mathrm{Sr}$ Care Pharm 2019;34:604-12.

153 Zhong Y, Patel N, Ferris M, et al. Health literacy, nutrition knowledge, and health care transition readiness in youth with chronic kidney disease or hypertension: a cross-sectional study. $J$ Child Health Care 2020;24:246-59.

154 Kindig DA, Panzer AM, Nielsen-Bohlman L, et al. Health literacy: a prescription to end confusion, 2004.
155 Williams TA, Wolf MS, Parker RM, et al. Parent dosing tool use, beliefs, and access: a health literacy perspective. J Pediatr 2019;215:244-51.

156 Winokur EJ, Rutledge DN, McGowan JJ. A picture is worth a thousand words: Pictographs to improve understanding of discharge instructions. J Emerg Nurs 2019;45:531-7.

157 Morrison AK, Myrvik MP, Brousseau DC, et al. The relationship between parent health literacy and pediatric emergency department utilization: a systematic review. Acad Pediatr 2013;13:421-9. 